Bulletin of Pharmaceutical Sciences
Assiut University

\title{
LEPTIN INTERRELATION BETWEEN ADIPOGENESIS AND ANGIOGENESIS WITH RESPECT TO THE INFLAMMATORY STATUS AND SEVERITY OF THE UNDERLYING NON-ALCOHOLIC FATTY LIVER DISEASES IN OBESE ALBINO RATS
}

\author{
Maiiada Hassan Nazmy ${ }^{1 *}$ and Manal Ismail Abdel-Ghany ${ }^{2}$ \\ ${ }^{1}$ Department of Biochemistry, Faculty of Pharmacy, Minia University, Minia 61111, Egypt \\ ${ }^{2}$ Department of Pathology, Faculty of Medicine, Minia University, Minia 61111, Egypt
}

\begin{abstract}
The present study aims to offer more reliable non-invasive markers for the distinction between pure fatty change and steatohepatitis.

Sixty male albino rats, equally divided into 4 groups (15 rats/group). Group I acted as normal control were fed standard diet. Groups II, III, IV were fed high fat diet for 4, 8, 12 weeks respectively.

High fat diet caused sustained hyperglycemia, hyperinsulinemia and insulin resistance. It also induced significant histopathological and biochemical changes in liver enzymes, lipid profile and lipid peroxidation. It significantly increased both serum and tissue levels of leptin, vascular endothelial growth factor, tumor necrosis factor-alpha and interleukin-6. All tested parameters were significantly correlated with histological scoring.

Suggested parameters, based on their involvement as key players in disease pathogenesis, may be useful as non-invasive diagnostic tools for obesity-related non-alcoholic fatty liver diseases.
\end{abstract}

\section{INTRODUCTION}

Non-alcoholic fatty liver diseases (NAFLDs) affect 10 to 24 percent of the general population ${ }^{1}$. They encompass a histological spectrum ranging from simple steatosis (i.e., fatty infiltration of the liver) to non-alcoholic steatohepatitis (NASH) (i.e., steatosis with inflammation and hepatocyte necrosis) $)^{2}$. Liver steatosis is a benign, nonprogressive condition, in contrast to NASH, which can progress to liver fibrosis, cirrhosis and eventually to hepatocellular carcinoma $(\mathrm{HCC})^{3}$. What exactly triggers the transition of liver steatosis to NASH is still a mystery. The pathogenesis of NASH comprises two steps ${ }^{4}$. First, the healthy liver becomes steatotic, mainly a consequence of peripheral resistance to insulin, whereby the transport of fatty acids from adipose tissue to the liver is increased. Although some protective mechanisms are developed to survive this stress, the fatty liver is in most cases particularly fragile and vulnerable to additional insults 5 . Then, a second step elicited by oxidative stress and inflammatory mediators occurs. This leads to exacerbation of insulin resistance, further oxidative stress, and organelle dysfunction within liver cells, resulting in an inflammatory process, hepatocellular degeneration, and fibrosis $^{6 \& 7}$. The pathogenesis of NAFLDs is still not fully understood, the recognised mechanisms do not fully explain the range of symptoms and physiological processes found in the disease progression. The pathophysiology of NAFLDs should probably be approached as a multifactorial process ${ }^{8}$.

Obesity may be considered one of the most important causal factors for NAFLDs. Adipose tissue participates in regulation of energy balance, glucose and lipid metabolism via the secretion of adipocytokines (i.e. leptin,

Received in 31/8/2014 \& Accepted in 2/12/2014 
adiponectin, tumor necrosis factor- $\alpha$ (TNF- $\alpha$ ) and Interleukin-6 (IL-6) ${ }^{9}$. Leptin, an adipocytederived hormone, regulates food intake and energy homeostasis. Functional impairment of leptin leads to severe obesity and diabetes ${ }^{10}$. TNF- $\alpha$ is synthesized and secreted by visceral adipocytes, stromovascular cells and macrophages. TNF- $\alpha$ mainly acts in an autocrine/paracrine fashion in adipose tissue and it plays a central role in the generation of insulin resistance in rodents. IL- 6 , on the other hand, is an endocrine cytokine with pleiotropic action ranging from inflammation to host defence (regulation of $\mathrm{B}$ and $\mathrm{T}$ cell functions) and tissue injury. IL-6 is closely associated with hyperinsulinemia and insulin resistance, and it may also play an important role in the pathogenesis of $\mathrm{NASH}^{6-9}$.

In several stages of NAFLDs, a link between the disease progression and hepatic microvasculature changes can be observed ${ }^{11}$. Angiogenesis, the formation of new blood vessels, is a key mechanism in the pathogenesis of chronic liver diseases, irrespective of their underlying aetiology ${ }^{12}$. Although multiple angiogenic factors have been identified in adipose tissue "i.e. vascular endothelial growth factor" (VEGF), little is known about the interplay between these factors in the adipose tissue environment ${ }^{13-15}$.

Construction of clearer boundaries between simple steatosis and steatohepatitis is still a clinical challenge that needs further examination. The present study aims to offer more reliable non-invasive markers for the distinction between pure fatty change and steatohepatitis by evaluation the possible role of leptin as a functional link between adipogenesis, angiogenesis and inflammatory status during progression of obesity-related NAFLDs.

\section{MATERIALS AND METHODS}

\section{Animals}

All animals received human care according to the National Institute of Health guidelines (USA). Sixty male albino rats (2 months old) weighing from (100-150 g) were procured from the central animal facility of the Institute. They were divided in to equal 4 experimental groups (15 rats/group). All rats were provided with commercially available rat normal pellet diet and water ad libitum, prior to the dietary manipulation. Individual body weights and food consumption were recorded weekly.

\section{Chemicals}

All chemicals and solvents used in the study were of analytical grade and were obtained either from Sigma Aldrich chemical company unless otherwise mentioned

\section{Diets}

Leiber-DeCarli (standard and high fat liquid) diets were used as follows:

1- Standard diet: (35\% of energy from fat, $47 \%$ from carbohydrates, $18 \%$ from protein $)^{16}$.

2- High fat diet: (71\% of energy from fat, $11 \%$ from carbohydrates, $18 \%$ from protein) ${ }^{17}$.

The diets were given ad libitum or as twothirds of the amount consumed ad libitum ${ }^{18}$.

\section{Experimental procedure}

1- Normal control: animals were fed standard diet for the whole period of experiment.

2- Simple steatosis (SS) group: animals were fed High fat diet (HFD) for 4 weeks.

3- Aggressive steatosis (AS) group: animals were fed HFD for 8 weeks.

4- Non-alcoholic Steatohepatitis (NASH) Group: animals were fed HFD for 12 weeks.

\section{Liver histopathology}

Histological evaluation was performed on a lobe of the liver and portion of specimen was fixed in $10 \%$ neutral formalin for $24 \mathrm{hrs}$ then changed to absolute ethanol for dehydration and embedded in paraffin wax. Sections were cut at $4 \mu \mathrm{m}$ in thickness, stained with hematoxylin and eosin for histological examination. Histopathological grading was performed according to the guidelines of Brunt et al. ${ }^{19}$. Histological scoring system for nonalcoholic fatty liver disease (NAFLD) was adopted from Kleiner $e t \mathrm{al}^{20}$.

\section{Plasma glucose and insulin levels}

Glucose levels were measured using a standard Randox glucose kit. Insulin levels were measured using insulin enzyme immunoassay kit following the instructions of the manufacturer. 


\section{Index of insulin resistance}

The index of insulin resistance estimated by the homeostasis model assessment insulin resistance (HOMA-IR) was calculated using the following formula ${ }^{21}$ :

$H O M A-I R=\frac{\operatorname{Insulin}(\mathrm{mUI} / \mathrm{L}) \times \text { Blood } \mathrm{glu} \cos e(\mathrm{mmol} / \mathrm{L})}{22.4}$

\section{Biochemical Analysis}

Liver Function tests (i.e. ALT, AST, GGT), Lipid profile (Total cholesterol, LDL, HDL, Triglycerides) were measured using standard Randox kits. Thiobarbituric acid reactive substances (TBARS) were measured using colorimetric kits (Cayman chemical company, USA), following the instructions of the manufacturer

\section{Enzyme-Linked Immunosorbent Assay (ELISA)}

Leptin, VEGF (Bio-Rad company, USA) and TNF-alpha, IL-6 (Abcam, USA) were measured by rat ELISA kits following the instructions of the manufacture.

\section{Western Blotting}

Up on determination of individual protein concentrations of the samples using Bradford assay $^{22}$, samples were prepared for loading. Aliquots of frozen hepatic homogenates were routinely examined by sodium dodecyl sulfate polyacrylamide gel electrophoresis followed by immunoblotting. Antibodies for Leptin, VEGF, TNF-alpha, IL-6 and actin were obtained from Abcam, USA.

\section{Statistical analysis}

Data were expressed as mean \pm SD. Data were analyzed using graph pad Prism statistical software version 5 (referenced for biochemical parameters). Qui square was used in western blot analysis. Statistical differences were calculated with ANOVA test for more than two groups. Pearson's rank correlation coefficient was used for evaluating the correlation between different biochemical variables. $\mathrm{p}<0.05$ was considered as significant.

\section{RESULTS AND DISCUSSION}

\section{Results}

Initial observations showed significant increase in food intake, final body weights and relative liver weight in HFD groups $(\mathrm{P}<0.01)$ compared to normal control. Blood insulin, glucose levels and HOMA-IR indices were also significantly higher in HFD groups $(\mathrm{P}<0.05)$ in groups II, III and $(\mathrm{P}<0.001)$ in group IV compared to normal control (Table 1).

Histological examination showed normal hepatic lobular architecture and normal hepatocytes with granulated cytoplasm and small uniform nuclei in group I (Fig. 1A). On the other hand, group II showed mild steatosis with no evidence of inflammation (Fig. 1B). Group III showed massive fat accumulation (both macroand micro- vesicular (Fig. 1C). Group IV showed periportal necrosis of the hepatocytes that surround the portal area associated with massive fat accumulation (both macro and microvesicular), ballooning degeneration, Malory's bodies and inflammatory infiltrate of mononuclear inflammatory cells (Fig. 1D, 1E).

Table 1: Body weight, food intake, plasma insulin, glucose and HOMA-IR index in different groups.

\begin{tabular}{|l|c|c|c|c||}
\hline & Normal Control & Simple Steatosis & $\begin{array}{c}\text { Aggressive } \\
\text { Steatosis }\end{array}$ & NASH \\
\hline Initial Body wt $(\mathrm{g})$ & $104 \pm 12.5$ & $101 \pm 14.7^{\mathrm{ns}}$ & $105 \pm 15.2^{\text {ns }}$ & $107 \pm 14.8^{\text {ns }}$ \\
\hline Final Body wt $(\mathrm{g})$ & $251 \pm 12.7$ & $295 \pm 13.9^{* * *}$ & $373 \pm 19.2^{* * *}$ & $430 \pm 15.5^{* * *}$ \\
\hline$\Delta$ Body wt $(\mathrm{g})$ & $147 \pm 11.2$ & $194 \pm 7.5^{* * *}$ & $268 \pm 6.3^{* * *}$ & $323 \pm 4.8^{* * * *}$ \\
\hline Absolute liver wt & $5.69 \pm 0.402$ & $7.58 \pm 0.44^{* *}$ & $11.41 \pm 1.42^{* * *}$ & $13.93 \pm 1.017^{* * *}$ \\
\hline Relative liver wt & $0.023 \pm 0.0023$ & $0.026 \pm 0.0029^{* *}$ & $0.031 \pm 0.0055^{* * *}$ & $0.033 \pm 0.0063^{* * *}$ \\
\hline Food intake (g/day) & $32 \pm 1.6$ & $65 \pm 4.9^{* * *}$ & $77 \pm 5.8^{* * *}$ & $85 \pm 7.9^{* * *}$ \\
\hline Insulin $(\mathrm{mUI} / \mathrm{L})$ & $10.53 \pm 0.66$ & $11.17 \pm 0.35^{* *}$ & $13.9 \pm 0.19^{* *}$ & $15.2 \pm 0.13^{* * *}$ \\
\hline Glucose $(\mathrm{mmol} / \mathrm{L})$ & $8.2 \pm 2.1$ & $9.7 \pm 3.7^{* *}$ & $11.7 \pm 3.1^{* * *}$ & $13.7 \pm 3.9^{* * *}$ \\
\hline HOMA-IR index & $3.85 \pm 0.047$ & $5.17 \pm 0.591^{* *}$ & $7.26 \pm 0.755^{* * *}$ & $9.29 \pm 0.912^{* * *}$ \\
\hline
\end{tabular}

Data are expressed as $\mathrm{X}^{-} \pm$SD of 10 rats in each group $(\mathrm{n}=10)$. Significant difference between groups is analyzed by t-student test, where: $(* * * \mathrm{P}<0.001, * * \mathrm{P}<0.01, * \mathrm{P}<0.05$ compared to normal control).

Relative liver $\mathrm{wt}=$ Absolute liver wt/Final body wt.

HOMA-IR= Insulin $(\mathrm{mIU} / \mathrm{L}) \times$ Glucose $(\mathrm{mmol} / \mathrm{L}) / 22$. 

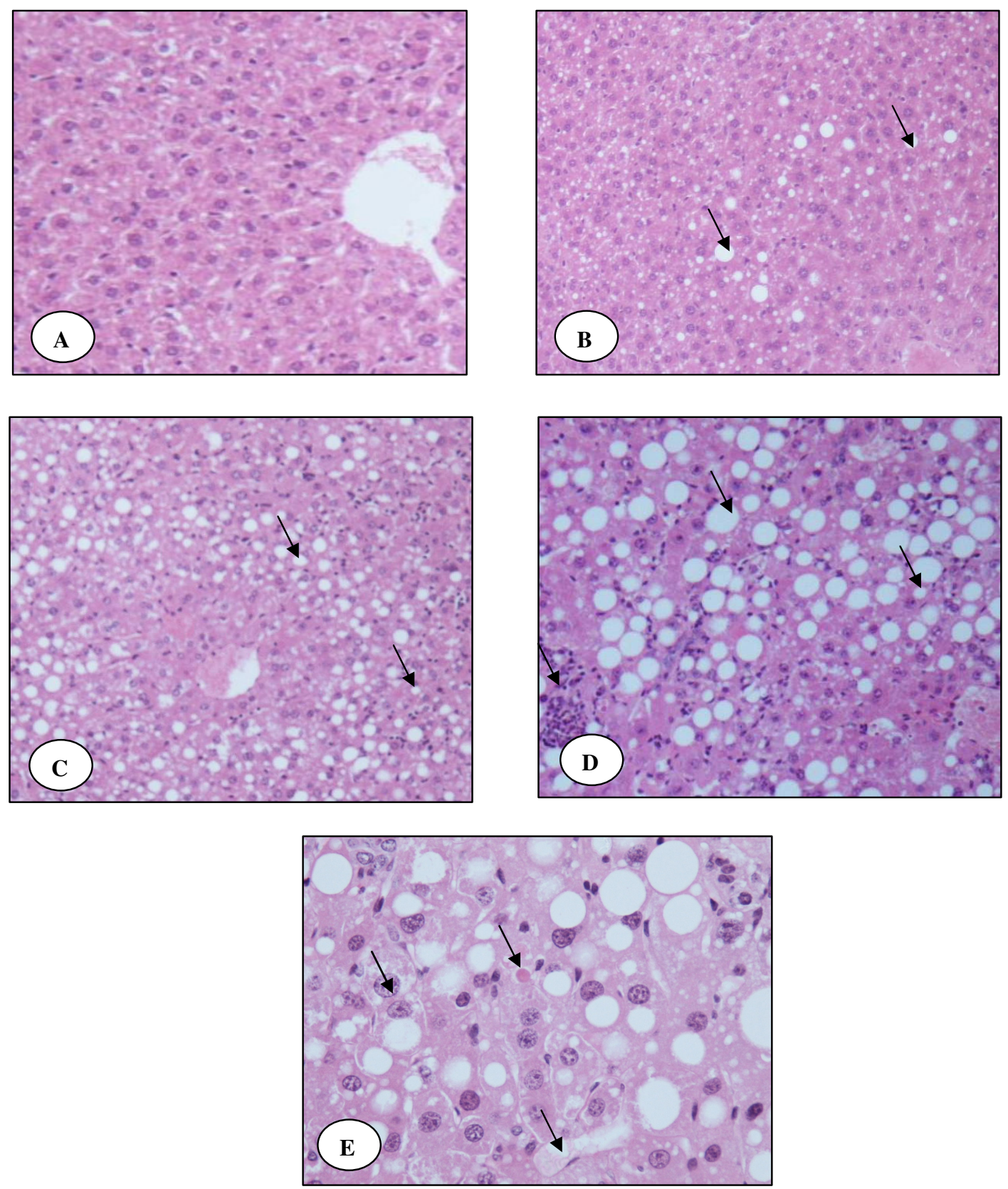

Fig. 1: Representative photomicrographs of liver sections from different groups.

A: Normal control: showed normal hepatic lobular architecture and normal hepatocytes with granulated cytoplasm and small uniform nuclei. B: Simple Steatosis group: Showed mild steatosis (mainly macrovesicular) with no evidence of inflammation. C: Aggressive Steatosis: Showed massive fat accumulation (both macro and micro vesicular). D and E: NASH group: showed periportal necrosis of the hepatocytes that surround the portal area associated with massive fat accumulation (both macro and micro vesicular), ballooning degeneration, Malory's bodies and inflammatory infiltration in the form of mononuclear inflammatory cell. 
Biochemical analysis also showed significant changes in liver enzymes, lipid profile and lipid peroxidation. Group I: did not show any significant changes in the tested parameters. Group II: showed significant changes in GGT $(\mathrm{P}<0.05)$, AST, LDL, HDL $(\mathrm{P}<0.01)$, total cholesterol, triglycerides and TBARS $(\mathrm{P}<0.001)$ except ALT which showed non significant change ( $>>0.05$ ). Group III, IV: both showed significant changes $(p<0.001)$ in all tested parameters (Table 2).

ELISA and WB were used to measure serum and tissue levels of leptin, VEGF, TNF$\alpha$ and IL-6. Leptin levels showed significant increase $(\mathrm{P}<0.001)$ in both serum and tissue. VEGF levels also showed significant increase $(\mathrm{P}<0.001)$ in both serum and tissue except in group II which showed non-significant increase $(\mathrm{P}>0.05)$. TNF- $\alpha$ levels showed significant increase $(\mathrm{P}<0.05)$ in group I and $(\mathrm{P}<0.001)$ in groups III and IV. IL-6 levels showed significant increase $(\mathrm{P}<0.001)$ in group $\mathrm{IV},(\mathrm{p}<$ $0.05)$ in group III and non-significant change $(\mathrm{P}>0.05)$ in group II (Table 3, Fig. 2).

Correlation analysis showed that all tested parameters were positively correlated with histological scoring (NAS) $(\mathrm{P}<0.05 ; \mathrm{r}=$ 0.9749, 0.9890, 0.9909, and 0.9832 for leptin, TNF- $\alpha$, IL-6 and VEGF respectively (Table 4).

Table 5 and figure 3 show ROC analysis including area under the curve (AUC), cut-off values, sensitivities, specificities and diagnostic accuracies for different markers. Overall diagnostic accuracy was calculated as the weighted average of a test's sensitivity and specificity. Diagnostic accuracy for all markers was 95 at cut off values > 5.7; 17.35; 45.15; 99.2 for leptin; TNF- $\alpha$; IL-6 and VEGF respectively.

Histopathological grading for hepatic findings revealed major changes in tested criteria (steatosis grade, affected zone, lobular inflammation grade (LIG), Spotty necrosis/apoptosis (NN/A) and finally cholestasis). Group I: did not show any abnormal findings (no signs for steatosis or inflammation). Group II: showed changes in only $20 \%$ of rats manifested by mild steatosis mainly macrovesicular with no sign of inflammation, necrosis/apoptosis or cholestasis. Group III: showed changes in $60 \%$ of rats manifested by moderate to severe steatosis with mild inflammation and less common necrosis/apoptosis or cholestasis. Group IV: showed typical signs of NASH in $100 \%$ of rats manifested by severe steatosis accompanied with moderate to severe inflammation with more common necrosis/apoptosis or cholestasis. Using NAFLDs scoring system (NAS) for histological scoring, groups I and II showed "NAS $\leq 2$ " in $100 \%$ of rats which corresponds to absence of NASH, group III showed "NAS: $3-4$ " in $30 \%$ of rats which corresponds to uncertain NASH, finally group IV showed "NAS $\geq 5$ " in $70 \%$ of rats which corresponds to definite NASH and "NAS: $3-4$ " in $30 \%$ of rats which corresponds to uncertain NASH (Table 6).

Table 2: Liver enzymes, lipid profile and TBARS in different groups.

\begin{tabular}{|l|c|c|c|c||}
\hline & Normal control & Simple Steatosis & Aggressive Steatosis & NASH \\
\hline ALT (IU/L) & $47.5 \pm 2.9$ & $48.28 \pm 3.2^{\mathrm{ns}}$ & $122 \pm 11.9^{* * * *}$ & $175.03 \pm 12.4^{* * * *}$ \\
\hline AST (IU/L) & $89.9 \pm 8.5$ & $103.5 \pm 10.9^{* *}$ & $208.4 \pm 15.6^{* * * *}$ & $243.4 \pm 22.7^{* * * *}$ \\
\hline GGT $(\mathrm{IU} / \mathrm{L})$ & $21.2 \pm 1.91$ & $25.3 \pm 3.79^{*}$ & $83.7 \pm 8.4^{* * *}$ & $125.4 \pm 11.1^{* * *}$ \\
\hline Total Cholesterol $(\mathrm{mg} / \mathrm{dl})$ & $98.9 \pm 9.8$ & $130.1 \pm 14.7^{* * *}$ & $173.3 \pm 18.4^{* * *}$ & $196.5 \pm 25.8^{* * *}$ \\
\hline Triglycerides $(\mathrm{mg} / \mathrm{dl})$ & $97.7 \pm 11.4$ & $139.5 \pm 16.4^{* * *}$ & $195.6 \pm 22.3^{* * *}$ & $226.8 \pm 23.9^{* * *}$ \\
\hline LDL $(\mathrm{mg} / \mathrm{dl})$ & $35.4 \pm 4.7$ & $42.9 \pm 6.5^{* *}$ & $87.3 \pm 8.4^{* * * *}$ & $135.2 \pm 14.1^{* * *}$ \\
\hline HDL $(\mathrm{mg} / \mathrm{dl})$ & $43.2 \pm 3.3$ & $36.8 \pm 4.2^{* *}$ & $22.6 \pm 1.8^{* * * *}$ & $14.8 \pm 1.3^{* * * *}$ \\
\hline TBARS $(\mu \mathrm{mol} / \mathrm{L})$ & $0.296 \pm 0.036$ & $0.574 \pm 0.074^{* * *}$ & $0.89 \pm 0.055^{* * *}$ & $1.45 \pm 0.012^{* * *}$ \\
\hline
\end{tabular}

Data are expressed as $X^{-} \pm S D$ of 10 rats in each group $(n=10)$. Significant difference between groups is analyzed by t-student test, where: $(* * * \mathrm{P}<0.001, * * \mathrm{P}<0.01, * \mathrm{P}<0.05$ compared to normal control). ALT: Alanine aminotransferase; AST: Aspartate aminotransferase; GGT; Gamma glutamyl transferase; LDL: Low density lipoprotein; HDL: High density lipoprotein; TBARS: Thiobarbituric acid reactive substances. 
Table 3: Serum levels of leptin, VEGF, TNF- $\alpha$, IL-6 in different groups.

\begin{tabular}{||c|c|c|c|c||}
\hline & Normal control & Simple Steatosis & Aggressive Steatosis & NASH \\
\hline Leptin $(\mathrm{ng} / \mathrm{ml})$ & $4.71 \pm 0.571752$ & $9.92 \pm 0.946361^{* * *}$ & $16.11 \pm 1.05019^{* * *}$ & $18.1 \pm 1.282965^{* * *}$ \\
\hline VEGF $(\mathrm{pg} / \mathrm{ml})$ & $88.21 \pm 8.349066$ & $107.574 \pm 4.480239^{\text {ns }}$ & $172.688 \pm 15.88789^{* * *}$ & $266.447 \pm 19.26743^{* * *}$ \\
\hline TNF- $\alpha(\mathrm{pg} / \mathrm{ml})$ & $15.84 \pm 1.585686$ & $22.19 \pm 2.725968^{*}$ & $84.24 \pm 7.36182^{* * *}$ & $105.93 \pm 9.938918^{* * * *}$ \\
\hline IL-6 $(\mathrm{pg} / \mathrm{ml})$ & $42.11 \pm 2.641761$ & $51.32 \pm 4.080392^{\text {ns }}$ & $66.12 \pm 4.301116^{* *}$ & $179.18 \pm 13.92284^{* * *}$ \\
\hline \hline
\end{tabular}

Data are expressed as $X^{-} \pm S D$ of 10 rats in each group $(n=10)$. Significant difference between groups is analyzed by t-student test, where: $(* * * \mathrm{P}<0.001, * * \mathrm{P}<0.01, * \mathrm{P}<0.05$ compared to normal control). TNF- $\alpha$ : Tumor necrosis factor- $\alpha$; IL-6: Interleukin-6; VEGF: Vascular endothelial growth factor.

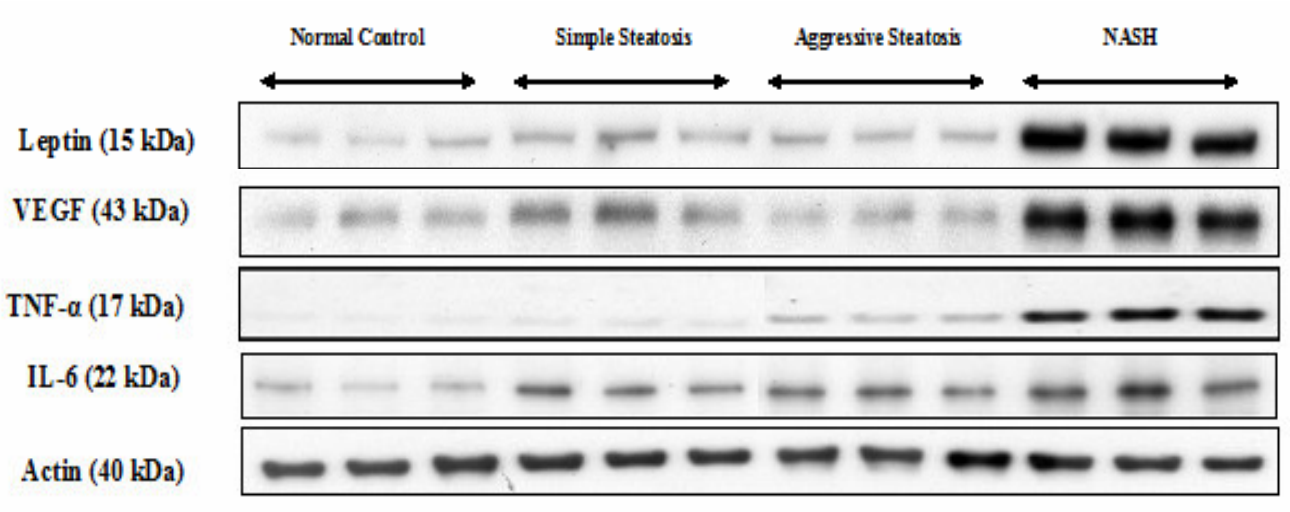

Fig. 2: Western Blotting for Leptin, VEGF, TNF- $\alpha$, IL-6 and Actin protein expression in the liver.

Table 4: Pearson's correlation coefficients for leptin, TNF- $\alpha$, IL-6 and VEGF versus NAS.

\begin{tabular}{||l|c|c|c|c|}
\hline \multicolumn{1}{|c|}{ Parameter } & Leptin & TNF-a & IL-6 & VEGF \\
\hline Pearson r & 0.9749 & 0.9890 & 0.9909 & 0.9832 \\
\hline $95 \%$ confidence interval & 0.2184 to 0.9995 & 0.5648 to 0.9998 & 0.6242 to 0.9998 & 0.4023 to 0.9997 \\
\hline P value (two-tailed) & 0.0251 & 0.0110 & 0.0091 & 0.0168 \\
\hline P value summary & $*$ & $*$ & $* *$ & $*$ \\
\hline $\begin{array}{l}\text { Is the correlation } \\
\text { significant? }\end{array}$ & Yes & Yes & Yes & Yes \\
\hline R squared & 0.9504 & 0.9782 & 0.9818 & 0.9668 \\
\hline
\end{tabular}


Table 5: AUC, cut-off values, sensitivities and specificities and diagnostic accuracies for different markers.

\begin{tabular}{||c|c|c|c|c|c||}
\hline \hline Parameter & AUC & Cut-off value & Sensitivity\% & Specificity\% & Diagnostic Accuracy \\
\hline Leptin & 1.00 & $>5.700$ & 100.0 & 90.00 & 95 \\
\hline TNF- $\alpha$ & 1.00 & $>17.35$ & 100.0 & 90.00 & 95 \\
\hline IL-6 & 1.00 & $>45.15$ & 100.0 & 90.00 & 95 \\
\hline VEGF & 1.00 & $>99.20$ & 100.0 & 90.00 & 95 \\
\hline
\end{tabular}

AUC $=$ area under the curve.

Overall diagnostic accuracy is the weighted average of a test's sensitivity and specificity.
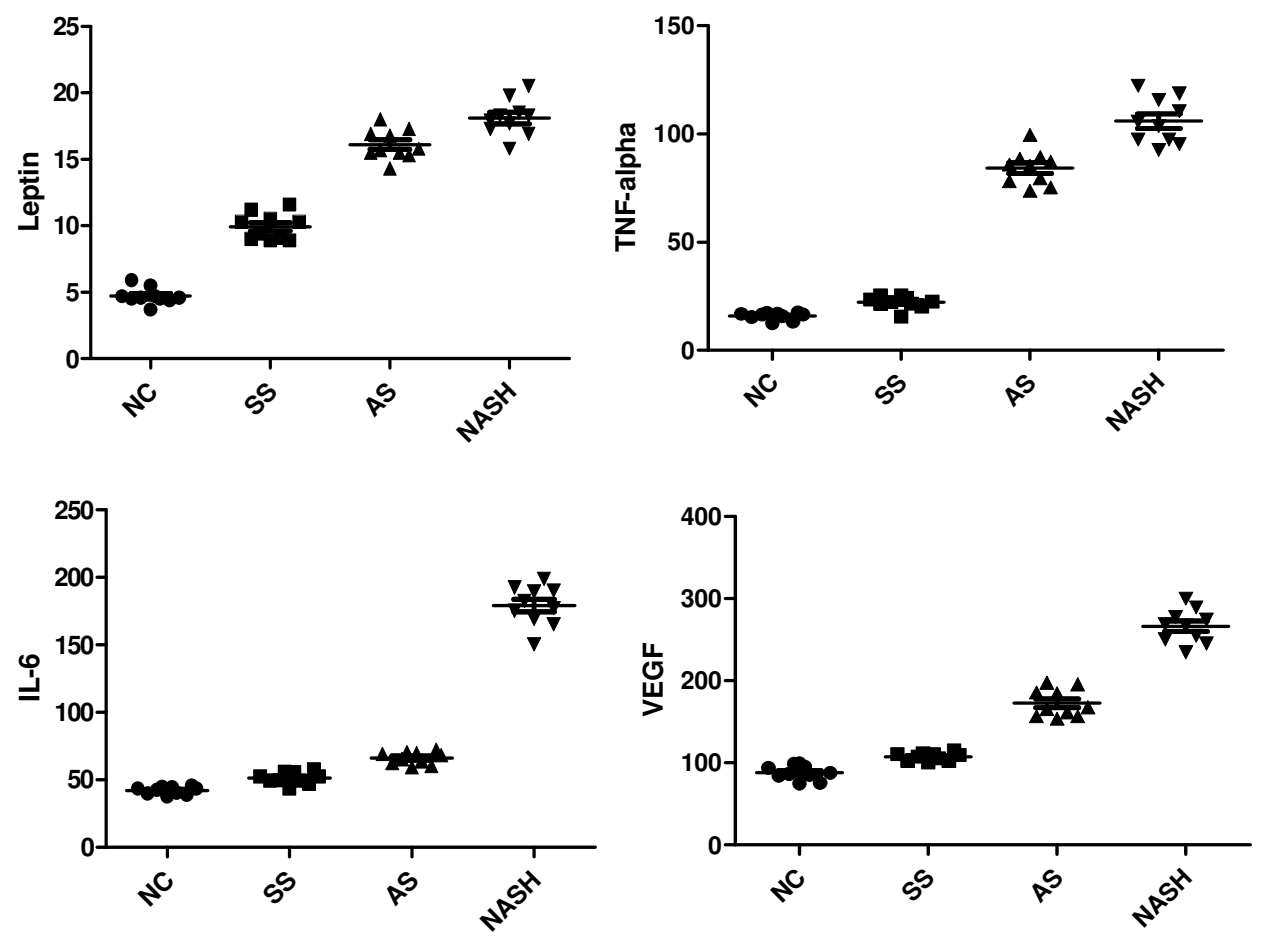

Fig. 3: ROC curves for different markers.

Table 6: Histopathological grading for liver samples. 


\begin{tabular}{|c|c|c|c|c|c|c|c|c|c|}
\hline No. & ID & $\begin{array}{c}\text { Steatosi } \\
\text { s } \\
\text { grade } \\
(0-3)^{\mathrm{a}}\end{array}$ & $\begin{array}{l}\text { Affected } \\
\text { zones }^{\mathrm{b}}\end{array}$ & $\begin{array}{c}\text { Steatosis } \\
\text { Type } \\
\text { (Vesicular) }\end{array}$ & $\begin{array}{l}\text { LIG } \\
(0-3)^{\mathrm{c}}\end{array}$ & $\begin{array}{l}\text { Hepatocyte } \\
\text { Balooning } \\
\quad(0-2)^{\mathrm{d}}\end{array}$ & $\begin{array}{c}\text { SN/A } \\
\text { Yes/ No }\end{array}$ & $\begin{array}{c}\text { Chole } \\
\text { Yes/ No }\end{array}$ & $\begin{array}{l}\text { NAS } \\
(0-8)^{\mathrm{f}}\end{array}$ \\
\hline 1 & $\mathrm{NC}(1)$ & 0 & NA & NA & 0 & 0 & $\mathrm{~N}$ & $\mathrm{~N}$ & 0 \\
\hline 2 & $\mathrm{NC}(2)$ & 0 & NA & NA & 0 & 0 & $\mathrm{~N}$ & $\mathrm{~N}$ & 0 \\
\hline 3 & $\mathrm{NC}(3)$ & 0 & NA & NA & 0 & 0 & $\mathrm{~N}$ & $\mathrm{~N}$ & 0 \\
\hline 4 & $\mathrm{NC} \mathrm{(4)}$ & 0 & NA & NA & 0 & 0 & $\mathrm{~N}$ & $\mathrm{~N}$ & 0 \\
\hline 5 & $\mathrm{NC}(5)$ & 0 & NA & NA & 0 & 0 & $\mathrm{~N}$ & $\mathrm{~N}$ & 0 \\
\hline 6 & $\mathrm{NC}(6)$ & 0 & NA & NA & 0 & 0 & $\mathrm{Y}$ & $\mathrm{N}$ & 0 \\
\hline 7 & $\mathrm{NC}(7)$ & 0 & NA & NA & 0 & 0 & $\mathrm{~N}$ & $\mathrm{~N}$ & 0 \\
\hline 8 & $\mathrm{NC}(8)$ & 0 & NA & NA & 0 & 0 & $\mathrm{~N}$ & $\mathrm{~N}$ & 0 \\
\hline 9 & $\mathrm{NC}(9)$ & 0 & NA & NA & 0 & 0 & $\mathrm{~N}$ & $\mathrm{~N}$ & 0 \\
\hline 10 & NC (10) & 0 & NA & NA & 0 & 0 & $\mathrm{~N}$ & $\mathrm{~N}$ & 0 \\
\hline 11 & SS (1) & 0 & NA & NA & 0 & 0 & $\mathrm{~N}$ & $\mathrm{~N}$ & 0 \\
\hline 12 & SS (2) & 2 & 2 & Macro & 0 & 0 & $\mathrm{~N}$ & $\mathrm{~N}$ & 2 \\
\hline 13 & SS (3) & 0 & NA & NA & 0 & 0 & $\mathrm{~N}$ & $\mathrm{~N}$ & 0 \\
\hline 14 & SS (4) & 0 & NA & NA & 0 & 0 & $\mathrm{~N}$ & $\mathrm{~N}$ & 0 \\
\hline 15 & SS (5) & 1 & 2 & Macro & 0 & 0 & $\mathrm{~N}$ & $\mathrm{~N}$ & 1 \\
\hline 16 & SS (6) & 0 & NA & NA & 0 & 0 & $\mathrm{Y}$ & $\mathrm{N}$ & 0 \\
\hline 17 & SS (7) & 0 & NA & $\mathrm{NA}$ & 0 & 0 & $\mathrm{~N}$ & $\mathrm{~N}$ & 0 \\
\hline 18 & SS (8) & 0 & NA & NA & 0 & 0 & $\mathrm{~N}$ & $\mathrm{~N}$ & 0 \\
\hline 19 & SS (9) & 0 & $\mathrm{NA}$ & NA & 0 & 0 & $\mathrm{~N}$ & $\mathrm{~N}$ & 0 \\
\hline 20 & SS (10) & 0 & NA & NA & 0 & 0 & $\mathrm{~N}$ & $\mathrm{~N}$ & 0 \\
\hline 21 & AS (1) & 0 & NA & NA & 1 & 0 & $\mathrm{~N}$ & $\mathrm{~N}$ & 0 \\
\hline 22 & AS (2) & 1 & 2 & Micro Macro & 1 & 0 & $\mathrm{~N}$ & $\mathrm{~N}$ & 2 \\
\hline 23 & AS (3) & 1 & 2 & Micro Macro & 0 & 0 & $\mathrm{~N}$ & $\mathrm{~N}$ & 1 \\
\hline 24 & AS (4) & 2 & 2,3 & Micro Macro & 1 & 0 & $\mathrm{~N}$ & $\mathrm{~N}$ & 3 \\
\hline 25 & AS (5) & 3 & 1,2 & Macro Micro & 1 & 0 & $\mathrm{Y}$ & $\mathrm{N}$ & 4 \\
\hline 26 & AS (6) & 0 & NA & NA & 0 & 0 & $\mathrm{~N}$ & $\mathrm{~N}$ & 0 \\
\hline 27 & AS (7) & 0 & NA & NA & 1 & 0 & $\mathrm{~N}$ & $\mathrm{~N}$ & 1 \\
\hline 28 & AS (8) & 0 & NA & NA & 1 & 0 & $\mathrm{~N}$ & $\mathrm{~N}$ & 1 \\
\hline 29 & AS (9) & 1 & 2 & Micro Macro & 0 & 0 & $\mathrm{~N}$ & $\mathrm{~N}$ & 1 \\
\hline 30 & $\operatorname{AS~(10)~}$ & 2 & 2,3 & Micro Macro & 1 & 0 & $\mathrm{~N}$ & $\mathrm{~N}$ & 3 \\
\hline 31 & NASH (1) & 2 & 2,3 & Macro Micro & 1 & 0 & $\mathrm{~N}$ & $\mathrm{Y}$ & 3 \\
\hline 32 & NASH (2) & 3 & 2,3 & Macro Micro & 3 & 0 & $\mathrm{Y}$ & $\mathrm{Y}$ & 6 \\
\hline 33 & NASH (3) & 3 & 2,3 & Macro Micro & 2 & 0 & $\mathrm{~N}$ & $\mathrm{Y}$ & 5 \\
\hline 34 & NASH (4) & 3 & $1,2,3$ & Macro Micro & 3 & 0 & $\mathrm{Y}$ & $\mathrm{N}$ & 6 \\
\hline 35 & NASH (5) & 3 & 2,3 & Macro Micro & 3 & 0 & $\mathrm{Y}$ & $\mathrm{N}$ & 6 \\
\hline 36 & NASH (6) & 1 & 2 & Micro & 2 & 1 & $\mathrm{~N}$ & $\mathrm{~N}$ & 4 \\
\hline 37 & NASH (7) & 2 & 2,3 & Macro Micro & 1 & 0 & $\mathrm{~N}$ & $\mathrm{Y}$ & 3 \\
\hline 38 & NASH (8) & 3 & 2,3 & Macro Micro & 3 & 0 & $\mathrm{Y}$ & $\mathrm{Y}$ & 6 \\
\hline 39 & NASH (9) & 3 & 2,3 & Macro Micro & 2 & 0 & $\mathrm{~N}$ & $\mathrm{Y}$ & 5 \\
\hline 40 & NASH (10) & 3 & $1,2,3$ & Macro Micro & 3 & 1 & $\mathrm{Y}$ & $\mathrm{N}$ & 7 \\
\hline
\end{tabular}

LIG= Lobule Inflammation Grade, $\quad$ SN/A= Spotty necrosis/Apoptosis,$\quad$ Chole $=$ Cholestasis

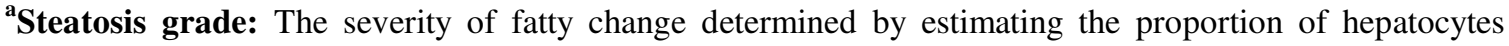
containing fat droplets $(0(<5 \%)=$ Minimal, $1(5-33 \%)=$ Mild, $2(33-66 \%)=$ Moderate, $3(>66 \%)=$ Severe, $\quad \mathrm{NA}=$ Not applicable $)$.

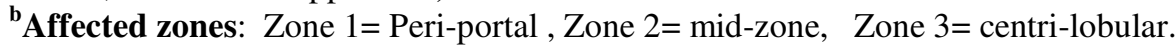

'Type of steatosis: when fat vesicles are large enough to distort the nucleus, the condition is known as macrovesicular steatosis; otherwise, the condition is known as microvesicular.

'Inflammation grade: severity of lobular inflammation based on inflammatory foci per x 200 field: $0=$ none, $1=1-2,2=$ up to $4,3=>4$.

${ }^{\mathrm{e}}$ Hepatocyte ballooning: $0=$ none, $1=$ few ballooned cells, $2=$ many cells $/$ prominent ballooning.

f Other tested criteria as necrosis and cholestasis were evaluated by their presence or absence (Yes/No).

${ }^{\mathrm{g}}$ NAFLD Activity Score (NAS) (0-8)= calculated as sum of scores for steatosis + lobular inflammation + hepatocellular ballooning (NAS $\geq 5$ (Probable or definite NASH), NAS (3-4) (Uncertain), NAS $\leq 2$ (Not $\mathrm{NASH})^{19 \& 20}$. 


\section{Discussion}

Understanding the pathogenesis of NAFLD is useful to identify effects and limitations of diagnostic techniques and therapeutic strategies ${ }^{23}$. The great majority of NAFLD occurs in the setting of metabolic syndrome in which insulin resistance plays a key role $^{24}$. It has been estimated that amongst a population of obese/diabetic individuals approximately $50-90 \%$ will have fatty change, 20-30\% will progress to steatohepatitisfibrosis and $2-5 \%$ will eventually become cirrhotic ${ }^{25}$. Although fatty change can be reliably diagnosed by non-invasive methods, the distinction between pure fatty change and steatohepatitis can still only be made histologically because of the generally poor correlation between clinical, biochemical and histological findings in NAFLDs ${ }^{26}$. To induce a reliable animal model for NASH, we selected a dietary model developed by Lieber and colleagues that reproduces the dominant clinical features of NASH in rats and mimics the human condition given that NASH is intimately associated with a fat-rich life-style in obese patients ${ }^{16-18}$.

Histopathological examination, grading and scoring clearly demonstrate that the ingestion of the Lieber liquid high-fat diet during 12 weeks produces all the prominent characteristics of NASH which are consistent with previous reports that illustrated typical features of steatohepatitis including hepatocellular injury (beyond simple fatty change), inflammatory infiltration, hepatocyte ballooning and Mallory's bodies besides other non-typical features like necrosis and cholestasis ${ }^{27}$.

High fat diet is a well characterized rodent model that results in hyperglycaemia, hyperinsulinemia, insulin resistance, defective islet compensation, impaired glucose tolerance and obesity ${ }^{28}$. The adipose tissue cells, called adipocytes are adapted to store large quantities of free fatty acids (FFA) to release them as a fuel on demand. An acquired adipocytokine profile during obesity influences FFA release from adipocytes with the consequent enhancement of lipid delivery to the liver ${ }^{29}$. Under normal conditions in liver cells lipids do not accumulate but rather are transformed into mixed particles like very low density lipoproteins which then can be secreted in the blood stream. The first event in the development of NAFLD is the accumulation of circulating FFA in the liver. They enter into liver cells by simple diffusion and accumulate in high amounts ${ }^{8}$. Whenever a large amount of FFA is present in the liver environment, liver cells increase lipid degradation pathways (lipolysis) but also suppress other pathways including insulin receptor activation, dysfunction of the insulin receptor causes hyperglycemia and secondary hyperinsulinaemia which are common features in the NAFLDs ${ }^{7 \& 30}$.

Our results showed highly significant positive correlation between serum levels of leptin, VEGF, TNF- $\alpha$ and IL-6 versus NAS, a standard scoring system for NAFLDs, which strongly suggests that these parameters can be used to monitor different developmental stages of NAFLDs to limit the use of invasive histopathological diagnostic techniques. There are conflicting reports about the exact role of leptin in the pathogenesis of NAFLD. Some studies demonstrated increased leptin levels in $\mathrm{NASH}^{31 \& 32}$, while others found no correlation between serum leptin levels and the development of NASH ${ }^{33 \& 34}$. The principal role of leptin may be to limit the accumulation of fat in non-adipose tissue, and reduce lipotoxicity. By increasing the supply of FFA to the liver, leptin induces dephosphorylation of insulin receptor substrate 1 to prevent hepatic fat accumulation ${ }^{35}$. On the other hand, high levels of serum leptin restrict fat mass expansion via endocrine stimulation of the central negative feedback loop, and paradoxically, leptin might promote adipogenesis through paracrine stimulation of angiogenesis ${ }^{36}$.

Mechanistically, very little is known about how adipokines are differentially regulated during adipose tissue growth. The crosstalk between adipocytes and endothelial cells is mediated by a number of angiogenic regulators, which cooperatively control vessel growth ${ }^{37}$. Interestingly, leptin is also defined as a potent angiogenic factor. The initial finding that endothelial cells express the functional long form of leptin receptor (OB-Rb) has led to the discovery of its angiogenic activity ${ }^{38}$. In addition to its direct angiogenic activity, leptin modulates VEGF-induced vascular activity by synergistically promoting neovascularization 
in-vivo. Leptin upregulates VEGF mRNA expression via activation of the Jak/Stat3 signaling pathway. Thus leptin may act as an indirect angiogenic factor or a modulator for other known angiogenic factors ${ }^{39}$.

Several proinflammatory cytokines may be pathogenetic in NAFLD. Although several studies have shown that TNF- $\alpha$ is a key factor in the development of NAFLD in both humans and animals, the role of this cytokine remains controversial $^{40 \& 41}$. In the adipose tissue, TNF- $\alpha$ acts by repressing genes involved in uptake and storage of non-esterified FFA ${ }^{42}$. These fatty acids are thus readily available to accumulate in non adipose tissues like the liver, increasing the pool of intrahepatic FFA. Increased levels of FFA can also induce TNF- $\alpha$ expression within the hepatocytes ${ }^{43}$. Collectively, IL-6 is overexpressed in the adipose tissue of obese patiens $^{44}$. Increased hepatic IL-6 production may play an important role in NASH. Chronically elevated IL-6 levels lead to inappropriate hyperinsulinaemia, impaired insulin-stimulated glucose uptake by the skeletal muscles and marked inflammation in the liver ${ }^{45 \& 4}$. In NAFLDs, increased serum levels of TNF- $\alpha$ and IL-6 may originate largely from adipose tissue ${ }^{47}$. In the liver, Kupffer cells are capable of releasing, among other factors, large quantities of TNF- $\alpha$ and IL- 6 directly in contact with liver cells influencing hepatic inflammation and fibrogenesis ${ }^{48-50}$.

\section{Conclusion}

The present results reflected a possible interrelation between adipogenesis, angiogenesis and inflammatory status which has an obvious impact on the severity of the underlying obesity related-NAFLDs. This study also highlighted a strong positive correlation between histopathological grading and scoring versus serum levels of our tested parameters (leptin, VEGF, TNF- $\alpha$, IL-6) which strongly suggest that these parameters, based on their involvement as key players in NAFLDS pathogenesis, may be useful as noninvasive diagnostic tools to differentiate between pure fatty liver and NASH in obese patients.

\section{Acknowledgemente}

This work was achieved by governmental funding from Faculty of Pharmacy - Faculty of Medicine, Minia University, Minia, Egypt.

\section{REFERENCES}

1- M. Lazo and J. M. Clark, "The epidemiology of nonalcoholic fatty liver disease: A global perspective", Semin Liver Dis., 28, 339-350 (2008).

2- E. M. Brunt, "Non-alcoholic steatohepatitis", ibid., 24, 3-20 (2004).

3- O. F. James and C. P. Day, "Non-alcoholic steatohepatitis (NASH): A disease of emerging identity and importance", $\boldsymbol{J}$. Hepatol., 29, 495-501 (1998).

4- C. P. Day and O. F. James, "Steatohepatitis: A tale of two "hits"", $\boldsymbol{J}$. Gastroenterol., 114, 842-845 (1998).

5- P. Angulo, "Nonalcoholic fatty liver disease", N. Engl. J. Med., 346, 1221-31 (2002).

6- C. P. Day, "From fat to inflammation", $J$. Gastroenterol., 130, 207-210 (2006).

7- I. A. Leclercq, M. A. Da Silva, B. Schroyen, H. N. Van and A. Geerts, "Insulin resistance in hepatocytes and sinusoidal liver cells: Mechanisms and consequences", J. Hepatol., 47, 142-156 (2007).

8- E. Bugianesi, A. J. McCullough and G. Marchesini, "Insulin resistance: A metabolic pathway to chronic liver disease", ibid., 42, 987-1000 (2005).

9- E. E. Kershaw and J. S. Flier, "Adipose tissue as an endocrine organ", J. Clin. Endocrinol Metab., 89 (6), 2548-2556 (2004).

10- F. Marra, "Leptin and liver fibrosis: A matter of fat", J. Gastroenterol., 122, 1529-32 (2002).

11- E. Xirouchakis, P. Manousou, L. Tsartsali, S. Georgopoulos and A. K. Burroughs, "Insights into the pathogenesis of NAFLD: The role of metabolic and proinflammatory mediators", Ann. Gastroenterol., 22 (1), 24-33 (2009).

12- A. Bouloumie, K. Lolmede, C. Sengenes, J. Galitzky and M. Lafontan, "Angiogenesis in Adipose Tissue", Ann. Endocrinol. (Paris), 63, 91-95 (2002). 
13- P. Carmeliet, "Angiogenesis in life, disease and medicine", Nature, 438, 932936 (2005).

14- H. F. Dvorak, "Angiogenesis: Update", $\boldsymbol{J}$. Thromb. Haemost., 3, 1835-1842 (2005).

15- N. Ferrara and R. S. Kerbel, "Angiogenesis as a therapeutic target", Nature, 438, 967-974 (2005).

16- C. S. Lieber and L. M. DeCarli, "Animal Models of Chronic Ethanol Toxicity". In: Packer L., Ed., "Methods in Enzymology: Oxygen Radical in Biological Systems", Vol. 233, Orlando, FL: Academic Press, Inc, 1994, pp. 585-94.

17- C. S. Lieber, M. A. Leo and K. M. Mak, "A model of non-alcoholic fatty liver disease (NAFLD), including steatohepatitis (NASH), in rats fed a high fat Lieber-DeCarli diet", J. Hepatol., 36, 402A, (2002).

18- C. S. Lieber, M. A. Leo, K. M. Mak, Y. $\mathrm{Xu}, \mathrm{Q}$. Cao, C. Ren, et al., "Model of nonalcoholic steatohepatitis", Am. J. Clin. Nutr., 79, 502-9 (2004).

19- E. M. Brunt, C. G. Janney, A. M. Di Bisceglie, B. A. Neuschwander-Tetri and B. R. Bacon, "Nonalcoholic steatohepatitis: A proposal for grading and staging the histological lesions", Am. J. Gastroenterol, 94, 2467-2474 (1999).

20- D. E. Kleiner, E. M. Brunt, M. Van Natta, C. Behling, M. J. Contos, O. W. Cummings, et al., "Design and validation of a histological scoring system for nonalcoholic fatty liver disease", $\boldsymbol{J}$. Hepatol., 41, 1313-1321 (2005).

21- D. R. Matthews, J. P. Hosker, A. S. Rudenski, B. A. Naylor, D. F. Treacher and R. C. Turner, "Homeostasis model assessment: Insulin resistance and betacell function from fasting plasma glucose and insulin concentrations in man", Diabetologia, 28 (7), 412-9 (1985).

22- M. M. Bradford, "A rapid and sensitive method for the quantitation of microgram quantities of protein utilizing the principle of protein-dye binding", J. Anal. Biochem., 72, 248-254 (1976).

23- S. Coulona, S. Francqueb, I. Collea, A. Verrijkenc, B. Blommea, F. Heindryckxa, et al., "Evaluation of inflammatory and angiogenic factors in patients with non- alcoholic fatty liver disease", Cytokine, 59, 442-449 (2012).

24- A. M. Diehl, Z. P. Li, H. Z. Lin and S. Q. Yang, "Cytokines and the pathogenesis of non-alcoholic steatohepatitis", Gut., 54, 303-306 (2005).

25- A. E. Reid, "Nonalcoholic steatohepatitis", J. Gastroenterol., 121, 710-723 (2001).

26- M. S. Ascha, I. A. Hanouneh, R. Lopez, T. A. Tamimi, A. F. Feldstein and N. N. Zein, "The incidence and risk factors of hepatocellular carcinoma in patients with nonalcoholic steatohepatitis", J. Hepatol., 51, 1972-1978 (2010).

27- B. A. Neuschwander-Tetri, J. M. Clark, N. M. Bass, M. L. Van Natta, A. UnalpArida, J. Tonascia, et al., "Clinical, laboratory and histological associations in adults with nonalcoholic fatty liver disease", Semin. Liver Dis., 52, 913-924 (2010).

28- R. Buettner, K. G. Parhofer, M. Woenckhaus, C. E. Wrede, L. A. KunzSchughart, J. Schölmerich, et al., "Defining high-fat-diet rat models: Metabolic and molecular effects of different fat types", J. Mol. Endocrinol., 36, 485-501 (2006).

29- R. H. Unger, "Lipotoxic diseases", Ann. Rev. Med., 53, 319-336 (2002).

30- F. Foufelle and P. Ferre, "New perspectives in the regulation of hepatic glycolytic and lipogenic genes by insulin and glucose: A role for the transcription factor sterol regulatory element binding protein-1c", Biochem. J., 366 (Pt 2), 377391 (2002).

31- S. Chitturi, G. Farrell, L. Frost, A. Kriketos, R. Lin, C. Fung, et al., "Serum leptin in NASH correlates with hepatic steatosis but not fibrosis: A manifestation of lipotoxicity?", J. Hepatol., 36, 403-9 (2002).

32- K. Nakao, K. Nakata, N. Ohtsubo, M. Maeda, T. Moriuchi, T. Ichikawa, et al., "Association between nonalcoholic fatty liver, markers of obesity, and serum leptin level in young adults", $\boldsymbol{A m}$. $\boldsymbol{J}$. Gastroenterol., 97, 1796-801 (2002).

33- N. Chalasani, D. W. Crabb, O. W. Cummings, P. Y. Kwo, A. Asghar, P. K. Pandya, et al. "Does leptin play a role in 
the pathogenesis of human nonalcoholic steatohepatitis?", ibid., 98, 2771-6 (2003).

34- M. G. Myers, M. A. Cowley and H. Munzberg, "Mechanisms of leptin action and leptin resistance", Ann. Rev. Physiol., 70, 537-556 (2008).

35- Y. Wang, K. K. Kuropatwinski, D. W. White, T. S. Hawley, R. G. Hawley, L. A. Tartaglia, et al., "Leptin receptor action in hepatic cells", J. Biol. Chem., 272, 1621623 (1997).

36- E. A. Tsochatzis, G. V. Papatheodoridis and A. J. Archimandritis, "Adipokines in nonalcoholic steatohepatitis: From pathogenesis to implications in diagnosis and therapy", Mediators of Inflammation, 2009, 8, (2009).

37- Y. Cao, "Angiogenesis modulates adipogenesis and obesity", J. Clin. Invest., 117 (9), 2362-2368 (2007).

38- D. M. McDonald and P. L. Choyke, "Imaging of angiogenesis from microscope to clinic", Nat. Med., 9, 713-725 (2003).

39- R. Cao, E. Brakenhielm, C. Wahlestedt, J. Thyberg and Y. Cao, "Leptin induces vascular permeability and synergistically stimulates angiogenesis with FGF-2 and VEGF", Proc. Natl. Acad. Sci. U.S.A., 98, 6390-6395 (2001).

40- F. Tacke, T. Luedde and C. Trautwein, "Inflammatory pathways in liver homeostasis and liver injury", Clin. Rev. Allergy and Immunol., 36 (1), 4-12 (2009).

41- K. L. Ma, X. Z. Ruan, S. H. Powis, Y. Chen, J. F. Moorhead and Z. Varghese, "Inflammatory stress exacerbates lipid accumulation in hepatic cells and fatty livers of apolipoprotein E knockout mice", J. Hepatol., 48, 770-781 (2008).

42- S. S. Koca, I. H. Bahcecioglu, O. K. Poyrazoglu, I. H. Ozercan, K. Sahin and B. Ustundag, "The treatment with antibody of TNF-alpha reduces the inflammation, necrosis and fibrosis in the non-alcoholic steatohepatitis induced by methionine- and choline-deficient diet", Inflam., 31, 91-98 (2008).
43- D. Lucero, V. Zago, G. I. López, M. Graffigna, H. Fainboim, V. Miksztowicz, et. al., "Pro-inflammatory and atherogenic circulating factors in non-alcoholic fatty liver disease associated to metabolic syndrome", Clin. Chim. Acta., 412, 143147 (2011).

44- H. Tilg and A. R. Moschen, "Adipocytokines: Mediators linking adipose tissue, inflammation and immunity", Nature Rev. Immunol., 6 (10), 772-783 (2006).

45- F. Marra and C. Bertolani, "Adipokines in liver diseases", J. Hepatol., 50 (3), 957969 (2009).

46- B. Wieckowska, G. Papouchado, Z. Lopez, R. Li, N. N. Zein and A. E. Feldstein, "Increased hepatic and circulating interleukin-6 levels in human nonalcoholic steatohepatitis", Am. J. Gastroenterol., 103 (6), 1372-1379 (2008).

47- M. J. Czaja, "Liver injury in the setting of steatosis: Crosstalk between adipokine and cytokine", J. Hepatol., 40, 19-22 (2004).

48- P. F. Lalor, J. Faint, Y. Aarbodem, S. G. Hubscher and D. H. Adams, "The role of cytokines and chemokines in the development of steatohepatitis", Semin Liver Dis., 27, 173-193 (2007).

49- S. E. Shoelson, J. Lee and A. B. Goldfine, "Inflammation and insulin resistance", $\boldsymbol{J}$. Clin. Invest., 116, 1793-1801 (2006).

50- H. H. Zhang, S. Kumar, A. H. Barnett and M. C. Eggo, "Tumour necrosis factoralpha exerts dual effects on human adipose leptin synthesis and release", Mol. Cell Endocrinol., 159, 79-88 (2000). 


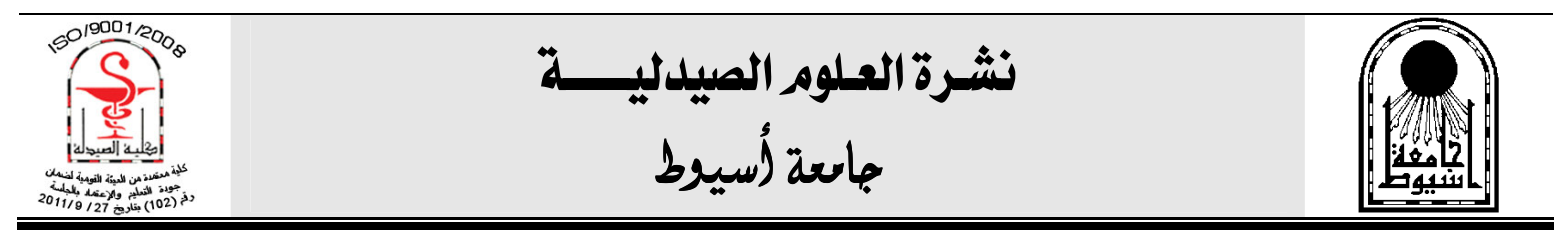

\section{علاقة اللبتين بين تكوين الدهون وتكوين بطانة الأوعية الدموية} بالنسبة للحالة الالتهابية وشدة أمراض اضلكين الكبد الدهنية الغير الكحولية الكوية الكامنة في الجرذان البيضاء البداء البناء

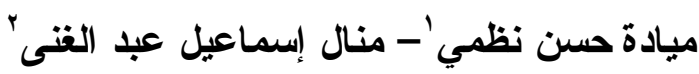

'قسم الكيمياء الحيوية ، كلية الصيدلة ، 'قسم علم الأمراض ، كلية الطب ، جامعة المنيا ، المنيا ل1/17 ،

$$
\text { مصر }
$$

تهذف هذه الدراسة إلى تقليم دلالات أكثر موثوقية واقل اختراقا للتمييز بين التغير الدهني و التهاب الكبد الدهني.

ستون من ذكور الجرذان البيضاء، مقسمة بالتساوي إلى ع مجموعات (10 الفئران/المجموعة).

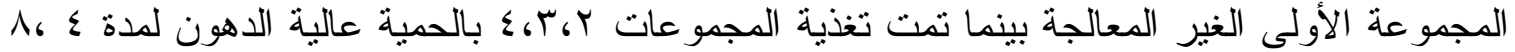

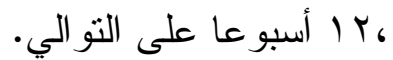

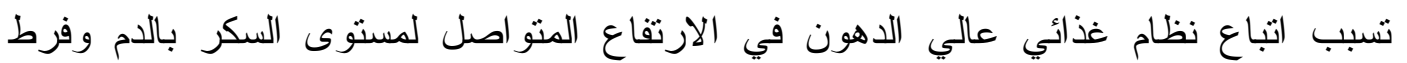

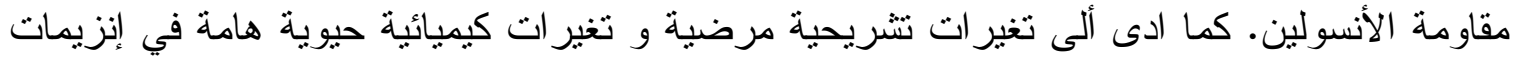

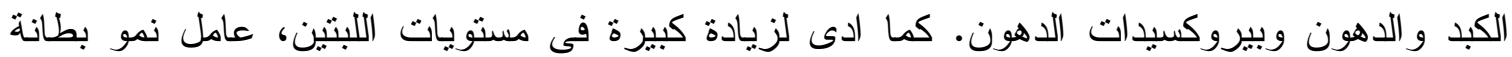

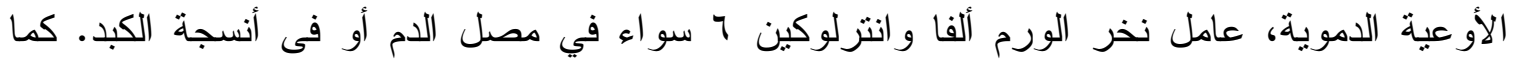
اظهرت جميع الدلالات النى تم قياسها ارتباطا احصائيا بالنسبة للتحليل النسيجى.

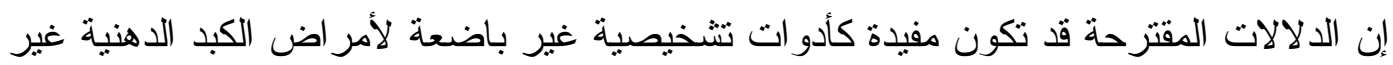

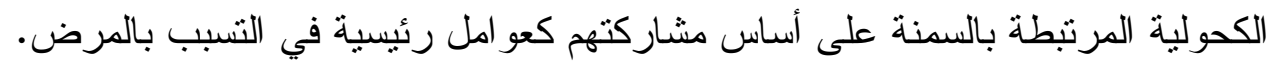

